\title{
Research on the Realization Path of Marxist Happiness View Education in Universities in the New Era
}

\author{
Xiaonan Li \\ School of Marxism, Xi'an FanYi University, Xi'an, Shaanxi, 710105
}

540120131@qq.com

Keywords: College students; Marxist outlook on happiness; Realization path; Chinese Dream

\begin{abstract}
The construction of socialism with Chinese characteristics has entered a new era. The education of college students' outlook on happiness should be guided by Marxist outlook on happiness and combined with the needs of the new era to form the scientific connotation of college students' correct outlook on happiness. The specific realization path is proposed from the following aspects of establishing the sense of ownership, strengthening social responsibility, studying diligently, working steadfastly, and devoting oneself to work. This study aims to can improve the ability of college students to pursue happiness, enrich the practice of college students' happiness experience, and promote college students to realize the value of life in the great practice of realizing the Chinese Dream.
\end{abstract}

\section{Introduction}

The concept of happiness is people's understanding of happiness, and different views of happiness have different pursuit of happiness. The President Xi Jinping said: "The new age is the age of strivers, and the happiness comes from struggle. Struggle itself is a kind of happiness. Only a life of struggle is a life of happiness. ${ }^{,[1]}$ Whether contemporary college students can establish a correct concept of happiness directly affects the realization of the socialist core values and the great rejuvenation of the Chinese nation.

\section{The Significance of Happiness View Education in Universities in the New Era}

If the teenager thrives, the country will thrive, and if the teenager is strong, the country will be strong, too. As an important part of ideological and political education in colleges and universities, the education of college students' outlook on happiness is bound to advance with the new era. The outlook of happiness is the core connotation of Marxism, which emphasizing the realization of human freedom and all-round development from creative labor in the dimension of organic unity of matter and spirit, individual and society ${ }^{[2]}$. College students' different understandings and pursuits of happiness are the concrete manifestation of their concepts of happiness in the real society. At present, most college students are single children, and they are used to being the focus of attention. This kind of characteristic weakens their sense of happiness, and makes them take the relatively rich life and superior environment as a matter of course, causing them to lack certain responsibility. Happiness is an overall category, which means that people live a better life on the whole. Family harmony, career success, proper behavior, and perfect personality are important factors of happiness. Some college students' outlook on happiness is distorted and misplaced, and there are some wrong inclinations of outlook on happiness, such as individualism, money worship and hedonism. Therefore, it is not only of great theoretical value, but also of practical significance to put the education of contemporary college students' outlook on happiness in the perspective of Marxism.

\section{The Scientific Connotation of Marxist Outlook on Happiness}

First of all,Marxist happiness holds that a person's happy life includes both material and spiritual life, both of which are indispensable. "Material life is the foundation of happiness and the necessary condition for human survival and development. Spiritual life is the sublimation of material life and 
is indispensable to human development." ${ }^{[3]}$ Happy life is inseparable from certain material conditions. In the process of pursuing the improvement of material living standard, everyone pays more attention to the pursuit of virtue and nobility of personality and the pursuit of healthy and upward spiritual life.

Secondly, personal happiness and social happiness are unified, and the two can not be separated from each other but depend on each other. Marx pointed out that: "The essence of man is not an abstraction inherent in a single individual. In reality, it is the sum of all social relations." ${ }^{\text {[4] }}$ Therefore, we can not separate personal happiness from social well-being. Marx wrote in his high school graduation thesis The Consideration of Youth Choosing Career: "If we choose the profession that works best for the happiness of mankind, the burden will not overwhelm us, because we are dedicated to humanity. Then what we feel is not pitiful, limited, and selfish fun, and our happiness may belong to millions of people." ${ }^{,[5]}$ Only in the process of contributing to society and serving others can we obtain the environment and conditions needed for happiness, create a greater sense of happiness, and realize the mutual promotion of individual happiness and social progress.

Finally, happiness is the unity of creation and enjoyment, but what is more important is labor and creation. "Labor creates material wealth and spiritual wealth, which is the basic source and realistic guarantee of human happiness." ${ }^{[6]}$ Creating happiness is the premise, and then we can talk about enjoying happiness. Under socialist conditions, only through the social practice and social labor can we achieve the goal of creating and enjoying happiness. "Happiness can't fall from the sky, and dreams will not come true automatically. All the happiness in the world needs to be created by hard work." $\left.{ }^{\text {, }}\right]$

\section{The Realization Path of Marxist Happiness View education in Universities}

"Marxist outlook on happiness is a kind of moral happiness view which combines happiness with morality and emphasizes dedication. The education of college students' outlook on happiness should be guided by it and takes it as the end result." ${ }^{,[8]}$ The education of happiness view in colleges and universities should be guided by Marxist happiness view to achieve the construction of "the greater self" that is the harmonious happiness of the whole society through the cultivation of the "small self" that is the cultivation of individual happiness view.

Firstly, to link individual happiness with the fate of the motherland and social progress to have the real happiness.

Happiness is the eternal pursuit of mankind and the ultimate goal of all goals. The Chinese Dream is a dream for the revitalization of the Chinese nation and a dream of becoming a talent for every college student. Today, the prime time in life of college students is exactly in line with the realization of the "two centenary goals". Individual happiness and social happiness are an organic unity. If college students do not care about national affairs, have no sense of collective honor and social responsibility, they can not make their due contributions to the development of the country and society. If they only blindly take from the society, or even damage the honor of their country for their own selfish ends, they will not get real happiness.

Secondly, with diligent learning, steadfast devotion and dedication to work to achieve the goal of happiness.

Young Marx has the ambition of "working for human beings". In order to realize his own ideal, he studies diligently and develops solid skills, which can be regarded as the model of every young man. During his time at the University of Berlin, Marx devoted almost all his time to intensive study and research. Merlin, a famous left-wing political activist, said in Biography of Marx that if Marx follows the institute's "feeding" approach, he will not complete what he have learned by himself in a year within ten years. In fact, each person's path to happiness may be different, but its commonality is that one's effort and harvest must be proportional to each other. To achieve the goal of happiness, college students must have the ability to pursue a happy life, and need to be down-to-earth and diligent.

Thirdly, to face the frustrations and hardships of real life to grasp the happy life.

"Happiness is a kind of satisfaction with inner desire, and happiness is a positive attitude towards 
life." ${ }^{,[9]}$ College happiness view education should help college students to establish a positive and optimistic attitude towards life, so that students' physical and mental health can be developed in an all-round way. Everyone's life can not always be successful, most of the time is in the ordinary, and even through numerous failures and adversities. If you face up your life's difficulties calmly and squarely, have the courage to accept the imperfection, timely summarize and learn lessons, it is to build energy reserves for a longer lasting happiness. When some college students encounter setbacks and difficulties in real life, they tend to produce negative and pessimistic emotions. However, the biggest obstacle is the obstacle from their own heart. If one sets happiness as the ultimate pursuit of life, putting fame, wealth and so on in the second place, and understanding that all the experiences in life are just for him to get more happiness, any setback in front of him is just a small hillside on the road to happiness. When you stand up and step on it, happiness is in your hands.

Fourthly, to cherish the present, learn to be grateful and tolerant to have a happy life.

The most precious thing in life is to hold the present moment and never lose the good time. Someone asked the scientist Hawking, "The illness has fixed you in a wheelchair forever. Don't you think that fate has made you lose too much?" Hawking smiled and struck the keyboard with only three fingers that could move, and wrote, "My fingers can move, my brain can think, I have a lifelong dream, I have loved me and my loved ones and friends, and I have a grateful heart!" Because of this optimistic attitude, Hawking was not overwhelmed by disease. He spread his free thought in the vast and profound universe, and solved numerous cosmic mysteries for mankind, which became the supernova in the international scientific community. No college students can grow up without the support and help of parents, teachers, relatives and friends from all walks of life. Only by honoring our parents, caring for family member, respecting teachers, and learning to be grateful can we better understand and appreciate happiness. To be grateful, the mind will grow wider and wider, and you can feel the beauty in the ordinary, so that the original dull things can change the charming brilliance. With gratitude, you will experience tolerance, harmony and warmth in your contentment.

Happiness is the eternal pursuit of human society. The happiness view education in colleges and universities in the new era is to help college students correctly understand the connotation of happiness, improve their ability to pursue happiness, enrich the practice of happiness experience, and strive to realize their own life value in the great practice of realizing the Chinese Dream under the guidance of Marxist outlook on happiness.

\section{Acknowledgement}

This paper is a project of "the 13th Five-Year Plan"of Shaanxi Education Science in 2016 (No. SGH16H307). A Practical Study on the Flipped Classroom Teaching Mode in Private Colleges and Universities - - Taking the Ideological and Moral Cultivation and Legal Basis Course as an Example.

\section{References}

[1] President Xi Jinping Delivers 2018 New Year's Greetings[N], People's Daily, 2018-01-01.

[2] S.W. Liu, J. Liu: Contemporary College Students' Happiness Education in the Context of Marxist Context[J],Heilongjiang Researches on Higher Education, (2017) No.10,p. 150.

[3] M.N.Qian, Y.G. Wang: On Marxist Concept of Happiness and Its Realization[J], Truth Seeking, (2016)No.4,p.13.

[4][5] Complete Works of Marx and Engels: The First Volume[M], Beijing: People's Publishing House, (1995),p.60, 460.

[6]Y.H.Yang: Marxist Concept of Labor and Happiness and Its Inspiration to Contemporary Youth[J], Journal of Shanghai Normal University(Philosophy and social science),(2017)No.1,p.22.

[7] Xi Jinping: The Governance of China[M], Beijing: Foreign Languages Press, (2014) p.4.

[8] Qingbi Qin: On the Education of Marxist Concept of Happiness in College Students[J], Journal 
of Guangxi Teachers Education University(Philosophy and social science), 2015, (5): 59. [9]Y.R.Zhu:“Happiness"Education in Outlook on Life[J], Forward Position,(2013)No.8,p.46. 